\title{
STANLEY V. LONG, 1937-1967
}

\author{
Clement W. Meighan
}

IN A TRAGIC accident, Stanley V. Long died I by drowning, in Colombia, while on a field expedition with a group of students from the Universidad de los Andes in Bogota. His death at the age of 30 deprives American archaeology of a vigorous and productive young researcher who had already made significant contributions to New World archaeology.

Although born in Idaho, Long spent most of his life in southern California and graduated from high school there. Following studies at Compton Junior College, he entered the University of California at Los Angeles, where he majored in anthropology, taking his B.A. in 1960, M.A. in 1962, and Ph.D. in 1966. He served as teaching assistant and teaching fellow at UCLA and took his first full-time teaching post as professor of anthropology at the Universidad de los Andes in Bogota, where he was serving as a faculty member at the time of his death.

I first met Long in 1958 when he was initiating his studies at UCLA. At that time he was very interested in flying and had an old Fairchild which he volunteered for aerial reconnaissance over the Borrego Desert of Southern California, a region then being surveyed by UCLA. He soon became actively involved in the field research programs at UCLA and worked on archaeological excavations in California; out of this experience grew his employment in 1962-63 as an archaeologist for the Archaeological Survey at UCLA.

In 1960 Long worked as a field archaeologist with me and H. B. Nicholson, who were then engaged in Project $A$ of the Interrelationships of New World Cultures program of the Institute for Andean Research. On this project Long took the major responsibility for the excavation and reporting of a deep shell midden at Barra de Navidad, Jalisco. Here he acquired one of his major interests: the archaeology of western Mexico, on which he did his doctoral dissertation and substantial field work. In 1961 he excavated (with H. B. Nicholson) a coastal site at Melchor Ocampo, Michoacan. In 1963-64, he developed, again with Nicholson, a program for the archaeology of Etzatlán, Jalisco. With National Science Foundation support, the field work was done by Long, and his doctoral disser- tation grew out of this program, being based on shaft-tomb finds from the Jalisco highlands.

On transfer of his professional interests to Colombia, Long immediately became active in several field programs of the Universidad de Los Andes and did excavations at Guapotá, Santander; Girardot, Tolima; and Tierradentro, Cauca. His manuscripts on these projects are being carried to completion by the Universidad de los Andes.

Stanley Long was a motivated scholar who had a rare dedication to archaeology and an enthusiasm for archaeological investigation. Problems of inadequate finances and uncomfortable working conditions never stopped him from doing his field work, and once the field work was done he could be depended upon to complete his written report thoroughly and promptly. In his death, American archaeology has lost one of its most able younger scholars.

Long is survived by his wife and two small sons.

\section{Bibliography of STANLEy V. LONG}

1964

Cire Perdue Copper Casting in Pre-Columbian Mexico: An Experimental Approach. American Antiquity, Vol. 30, No. 2, pp. 189-92. Salt Lake City.

1966

Archaeology of the Municipio of Etzatlan, Jalisco. Doctoral dissertation, published by University Microfilms, Inc., Ann Arbor (also scheduled for publication by the Middle American Research Institute, Tulane University).

(with Marcia Wire) Excavations at Barra de Navidad, Jalisco. Antropologica, No. 18 (81 pp.) Editorial Sucre, Caracas.

(with R. E. Taylor) The Chronology of a West Mexican Shaft-Tomb. Nature, Vol. 212, No. 5062, pp. 651-2, London.

(with R. E. Taylor) Suggested Revision for West Mexican Archaeological Sequences. Science, Vol. 154, No. 3755, pp. 1456-9. Washington.

\section{7}

Forma y distribucion de tumbas de Pozo con camara lateral. Revista de la Universidad de los Andes, No. 1, pp. 1-8. Bogota.

1968

Chibcha Stone Models for Cire Perdue Casting. Museo de Oro del Banco de la Republica, Bogota. (in press)

University of CaLIFornia Los Angeles, California July, 1968 